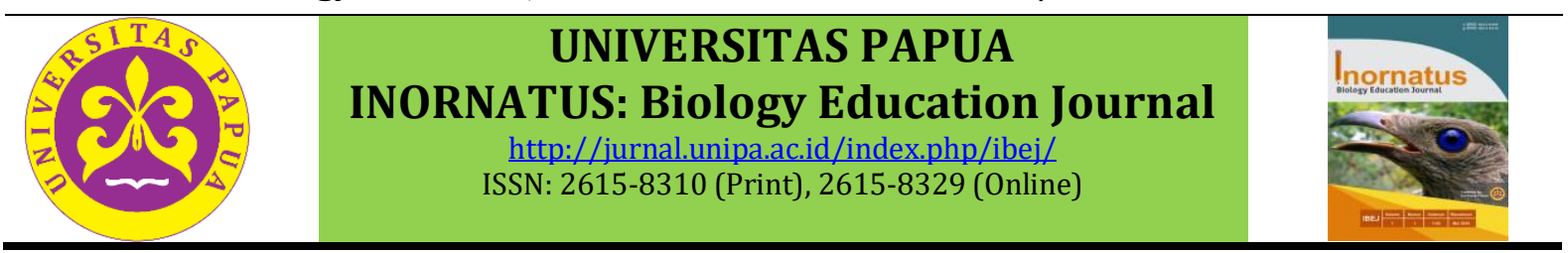

\title{
Examining student learning outcomes on the topic of invertebrates through problem-based learning
}

\section{Meneliti hasil belajar siswa pada topik invertebrata melalui pembelajaran berbasis masalah}

\author{
Nur Lailil Zannah ${ }^{1,}{ }^{*}$, Insar Damopolii1, Iwan Iwan'1, Sari Rahayu Rahman ${ }^{2}$ \\ 1Universitas Papua, Indonesia \\ 2Universitas Sulawesi Barat, Indonesia \\ *korespondensi penulis : nurlaililzannah75@gmail.com
}

\begin{abstract}
The research aims to examine the effect of treatment with the application of problem-based learning (PBL) on learning outcomes of student. The topic of teaching biology in this research is invertebrate material. During the conduct of this research, a quasi-experimental non-equivalent control group program was done. A total of 45 students who were divided into two classes (control $=20$ students, experiment $=$ 25 students) were taken randomly from a total of eight classes. The instrument for measuring student learning outcomes is seven items and has been validated by experts and empirically. The t test was used to compare data. The results of the research show that there is no difference in learning outcomes in the two classes (experimental and control) with sig. 0.825. This research concludes that problem-based learning has no impact on student learning outcomes on invertebrate material. The future research recommendation is to provide innovation in problem-based learning to increase its effectiveness on student performance.
\end{abstract}

Keywords: PBL, learning outcome, invertebrate, biology learning

\begin{abstract}
Abstrak
Riset bertujuan mengkaji efek perlakukan dengan penerapan pembelajaran berbasis masalah (PBM) terhadap hasil belajar siswa. Topik pengajaran biologi dalam riset ini adalah materi invertebrata. Kuasi eksperimen desain non-equivalent control group digunakan dalam riset eksperimen ini. Sebanyak 45 siswa yang terbagi menjadi dua kelas (kontrol = 20 siswa, eksperimen $=25$ siswa) yang diambil secara acak dari total delapan kelas. Instrumen pengukur hasil belajar siswa berjumlah tujuh item dan telah tervalidasi ahli dan empirik. Analisis data menggunakan uji t. Hasil riset mengindikasikan bahwa tidak ada perbedaan hasil belajar pada kedua kelas (eksperimen dan kontrol) dengan nilai sig. 0,825. Riset ini menyimpulkan bahwa PBM tidak berdampak terhadap capaian belajar siswa pada materi invertebrata. Rekomendasi riset selanjutnya adalah memberikan inovasi pada pembelajaran berbasis masalah untuk meningkatkan efektivitasnya terhadap performa siswa.
\end{abstract}

Kata Kunci: PBM, hasil belajar, invertebrata, pembelajaran biologi

\section{Pendahuluan}

Pembelajaran biologi memiliki berbagai macam topik untuk dipelajari. Salah satu topik yang diajarkan adalah materi invertebrata. Khairi, Widyanto, dan Agustina, (2015) dalam artikel mereka menjelaskan bahwa materi invertebrata membutuhkan penjelasan mendalam tetapi keterbatasan fasilitas membuat bekurangnya kreativitas guru. Dampaknya adalah kelas tidak menarik dan membuat materi ini terasa sulit. Fasilitas pembelajaran memberi dampak terhadap kualitas pembelajaran (Frabun, Iwan, \& Wambrauw, 2018; Watem, Nunaki, \& Wambrauw, 2018). Sari dan Faizah, 
(2018) berdasatkan observasi mereka menemukan bahwa siwa kesulitan untuk mengklasifikan hewan ketika materi invertebrata diajarkan. Penyebab lain sulitnya siswa memahami materi invetrebrata adalah keluasan materi ini (Hapsari, 2016).

Jika dalam penyampaian materi digunakan dengan menggunakan pembelajaran konvensional tanpa adanya variasi, siswa menjadi bosan dan kurang terlibat dalam proses pembelajaran. Kondisi ini menyebabkan proses pembelajaran menjadi berpusat pada guru. Ketika guru berhalangan hadir dalam kelas, guru hanya memberi tugas yang mana nilai tersebut dijadikan nilai tugas ataupun nilai ulangan harian. Siswa akan mengerjakan tanpa memahami materi tersebut dan adanya kemungkinan siswa yang malas ataupun kurang dari segi kemampuan kognitif. Banyak siswa menyalin tugas langsung dari teman tanpa mengetahui apa yang sedang ia kerjakan. Tidak adanya alat peraga atau media penunjang pembelajaran, sebagian besar siswa tidak memiliki buku pegangan siswa. Pembelajaran dengan model konvensionl menyebabkan beberapa orang siswa tidak dapat memenuhi KKM 75. Hal ini terbukti berdasarkan adanya temuab data yang mengungkap bahwa capaian belajar siswa masih rendah. Ditunjukkan oleh hasil belajar di kelas X MIA ${ }^{1}$ terdapat $25 \%$ siswanya yang tidak tuntas dari jumlah 28 siswa, kelas X MIA ${ }^{2}$ terdapat 20\% siswanya tidak mencapai tuntas dari jumlah 30 siswa. Proses pembelajaran yang tidak diperbaiki menyebabkan kemunduran terhadap hasil belajar siswa (Posangi, Hasan, \& Dama, 2018). Hasil belajar siswa penting dalam menentukan keberhasilan pembelajaran (Damopolii, Yohanita, Nurhidaya, \& Murtijani, 2018).

Pembelajaran dapat diperbaiki dengan penggunaan pembelajaran berbasis masalah (PBM). PBM dapat meningkatkan motivasi, berpikir kritis (Nargundkar, Samandar, \& Mukhopadhyay, 2014) dan keterampilan proses sains (Yuliati, 2016). Menjadikan siswa kreatif (Khoiriyah \& Husamah, 2018), mampu bernalar dan memecahkan masalah (Misnasanti, Utami, \& Suwanto, 2017), meningkatkan hasil belajar (Damopolii, Nunaki, \& Supriyadi, 2018), Kualitas pembelajaran (Yusuf \& Widyaningsih, 2018), dan siswa sukses dalam belajar (Fatmasuci, 2017). PBM memberikan dampak lebih baik terhadap capaian belajar dibandingkan dengan tanpa penggunaan PBM (pembelajaran konvensional) (Mulyanto, Gunarhadi, \& Indriayu, 2018). PBM menjadi solusi untuk memperbaiki hasil belajar siswa. Beberapa hasil riset juga menunjukkan PBM adalah baik bagi siswa. Permasalahan dalam materi invertebrata dapat diatas dengan PBM. Riset ini Riset bertujuan mengkaji efek perlakukan dengan penerapan PBM terhadap hasil belajar siswa.

\section{Metode}

Penelitian dilaksanakan di salah satu SMA Negeri di Manokwari. Populasi dalam penelitian adalah seluruh siswa kelas X SMA yang berada pada 8 kelas. Sampel yang digunakan dalam penelitian adalah 2 kelas dengan jumlah 45 siswa. Sebanyak 25 orang siswa di kelas PBM (eksperimen) 20 siswa di kelas konvensional (Kontrol).

Perangkat penelitian yang digunakan oleh peneliti berupa RPP / Rencana Pelaksanaan Pembelajaran, LKPD / Lembar Kerja Siswa, dan Tes Hasil Belajar. Analisis validasi konten untuk setiap item / butir soal menggunakan persamaan Content Validity Ratio (CVR). Keputusan instrumen valid diamnil apabila hasil CVR berada pada rentang 0 - 1. Perhitungan nilai CVR menggunakan rumus dari Lawshe, (1975). Reliabilitas menggunakan alpha Cronbach.

Pembelajaran dilaksanakan selama 270 menit, dimana diberikan tes dua kali (pretest dan posttest) untuk setiap kelas. Analisis data dikalkulasi dengan uji t 
independen dan persyaratan analisis menggunakan Kolmogorov (pemgujian normalitas) dan uji levene (pengujian homogenitas).

\section{Hasil dan Pembahasan}

Hasil penelitian menghadirkan beberapa data seperti hasil validasi ahli dan empirik, normalitas, homogenitas dan hasil uji perbedaan. Berikut disajikan hasil analisis data.

Tabel 1. Hasil validasi perangkat dan instrumen

\begin{tabular}{lcl}
\hline Aspek Yang Dinilai & $\overline{\boldsymbol{x}}$ & Kriteria \\
\hline Tes Hasil Belajar & 1 & Valid \\
LKPD & 1 & Valid \\
RPP & 1 & Valid \\
\hline
\end{tabular}

Tabel 2 Hasil uji empirik tes hasil belajar (THB)

\begin{tabular}{cccccc}
\hline Item (I) & Sig. & Ket. & Item & Sig. & Ket. \\
\hline I1 & 0,061 & Tidak Valid & I5 & 0,001 & Valid \\
I2 & 0,000 & Valid & I6 & 0,000 & Valid \\
I3 & 0,000 & Valid & I7 & 0,000 & Valid \\
I4 & 0,003 & Valid & I8 & 0,004 & Valid \\
\hline
\end{tabular}

Reliabilitas $\alpha$ Cronbach $=0,771 \quad$ Reliabel

Berdasarkan data pada Tabel 1 dan 2 ditemukan bahwa perangkat dan instrument penelitian memenuhi kriteteria valid. Terdapat tujuh item yang valid untuk tes hasil belajar berdasarkan hasil uji coba empirik.

Tabel 3. Deskripsi data pretest dan posttest

\begin{tabular}{lllll}
\hline \multirow{2}{*}{ Deskripsi } & \multicolumn{3}{c}{ Pretest } & Posttest \\
\cline { 2 - 5 } & Kontrol & Eksperimen & Kontrol & Eksperimen \\
\hline Nilai tertinggi & 33 & 57 & 65 & 83 \\
Nilai terendah & 10 & 0 & 23 & 20 \\
Mean & 19,45 & 19,88 & 43,75 & 44,72 \\
Median & 17,50 & 16,00 & 43,00 & 45,00 \\
Standar deviasi & 6,75 & 16,32 & 11,42 & 16,56 \\
\hline
\end{tabular}

Hasil perhitungan menunjukkan bahwa mean pretes kontrol dan eksperimen berbeda sebesar 0.43 dengan nilai tertinggi 33 (kontrol) dan 57 (eksperimen). Walaupun nilai posttest mencapai maksimal 83 (eksperimen) dan 65 (kontrol), perbedaa data posttest hanya sebesar 0.97 .

Tabel 4. Hasil pengujian normalitas dan homogenitas

\begin{tabular}{lccccc}
\hline \multirow{2}{*}{ Kelompok Data } & \multicolumn{3}{c}{ Normalitas } & \multicolumn{2}{c}{ Homogenitas } \\
\cline { 2 - 6 } & Df & Sig. & Putusan & Sig. & Putusan \\
\hline Pretest Kontrol & 20 & 0,198 & Normal & \multirow{2}{*}{0,005} & \multirow{2}{*}{ Tidak Homogen } \\
Pretest Eksperimen & 25 & 0,200 & Normal & & \\
Posttest Kontrol & 20 & 0,200 & Normal & 0,076 & Homogen \\
Posttest Eksperimen & 25 & 0,200 & Normal & & \\
\hline
\end{tabular}


Hasil uji normalitas dalam Tabel 4 menindikasikan bahwa semua data (pretest dan posttest) berdistribusi normal. Untuk hasil pengujian homogenitas, data pretest tidak memenuhi kriteria, tetapi masih dapat dilakukan pengujian dengan menggunakan uji t.

Tabel 5. Hasil uji t

\begin{tabular}{llcccc}
\hline & Data & t & Df & Sig. & Keputusan \\
\hline Pretest & Equal variances not assumed & $-0,120$ & 33,43 & 0,906 & Tidak berbeda \\
\hline Posttest & Equal variances assumed & $-0,232$ & 42,18 & 0,825 & Tidak berbeda \\
\hline
\end{tabular}

Karena hasil pengujian pengaruh rata-rata data pretest pada kedua kelas yang dihadirkan pada Tabel 5 menunjukkan bahwa, bila menggunakan Equal variances tidak diasumsikan, signifikansi untuk kelas kontrol dan kelas eksperimen adalah 0,906 >0,05 maka dapat dinyatakan bahwa kemampuan awal siswa sama. Begitu juga hasil akhir siswa mengungkap tidak adanya perbedaan $(0,825>0,05)$.

Pada awal pembelajaran siswa di kedua kelas telah diberikan pretest untuk mengetahui kemampuan awal siswa sebelum masuk pada materi. Berdasarkan data hasil pretest kelas kontrol (rata-rata hasil sebesar 19.75) dan kelas eksperimen (ratarata hasil 19,88 ) menunjukkan selisih skor kecil. Kedua kelas tersebut tidak memiliki perbedaan (sig. > 0,05). Rendahnya rata-rata hasil pretest dari kedua kelas tersebut dikarenakan materi yang di ujikan belum di ajarkan sebelumnya, sehingga siswa menjawab sesuai apa yang mereka ketahui saja. Siswa di kelas kontrol dan eksperimen mengambil posttest pada akhir penelitian untuk menilai apakah kemampuan mereka telah berubah sebagai akibat dari partisipasi mereka dalam mengikuti pembelajaran. Berdasarkan hasil posttest kelas kontrol dan kelas eksperimen, dapat diputuskan bahwa rata-rata hasil posttest kelas eksperimen $(44,72)$ lebih tinggi dibandingkan dengan kelas kontrol (43,75). Hasil uji inferensial (uji t) mengungkap bahwa hasil belajar antara PBM dan konvensional tidak berbeda (sig. $=0,825$ ).

Dari penelitian yang dilakukan oleh Ayyildiz dan Tarhan, (2018); Damopolii, Yohanita, Malatta, dan Yusuf (2018) yang menggunakan PBM mendapatkan hasil yang menyatakan bahwa PBM dapat mendorong ke arah lebih baik hasil belajar siswa. Namun, dari hasil penelitian yang kami peroleh bahwa perbedaan tidak signifikan antara PBM dengan konvensional. Hal tersebut terjadi dikarenakan beberapa faktor diantaranya, seperti model yang digunakan oleh peneliti yaitu PBM ini baru diterapkan pada siswa yang menjadi sampel. Pembelajaran ini baru mereka dapatkan dalam proses pembelajaran. Selama ini siswa hanya diajarkan dengan model konvensional dan diskusi kelompok biasa dan kurangnya variasi, sehingga siswa ketika diterapkan PBM para siswa masih kesusahan dalam menerapkan proses pembelajaran ini, karna hal-hal tersebut siswa masih belum mampu menanamkan konsep materi dengan baik dalam pikiran mereka. Selain itu disebabkan oleh keterbatasan waktu karena siswa sulit dalam memahami proses pembelajaran ini sehingga peneliti harus mengajarkan pada masingmasing kelompok dan memberi penjelasan pada setiap kelompok secara berulang-ulang tentang pembelajaran dengan PBM. PBM tidak efektif karena kekurangan bimbingan (Baran \& Sozbilir, 2018). Penelitian lain menemukan bahwa PBL tidak memberikan pengaruh terhadap performa siswa (Pardamean, 2012; Ulger, 2018).

Selain kedua faktor tersebut, materi menjadi kendala dalam proses pembelajaran dimana peneliti menggunakan materi animalia terkhusus pada sub materi invertebrata yang mana telah diketahui bahwa hewan-hewan yang termasuk didalamnya merupakan hewan yang berhabitat dilaut. Peneliti telah memberi permasalahan dunia nyata tetapi karna beberapa masalah yang disajikan terkait dengan hewan yang berhabitat di laut 
sehingga siswa tidak dapat mempelajari dengan pengamatan langsung. Kurangnya pengalaman dari para siswa yang menyebabkan para siswa kesulitan dalam pemecahan masalah tersebut, sehingga peneliti beranggapan bahwa materi ini kurang cocok untuk digunakan PBM. Dapat saja digunakan PBM tetapi dengan melakukan observasi langsung di laut. Karena jarak antara letak sekolah dengan laut sangatlah jauh maka tidak dapat dilakukan observasi langsung. Hal ini sejalan dengan kelemahan dari model Problem Based Learning (PBL) yang dikemukankan oleh Saleh (2013) bahwa tidak semua materi dapat diterapkan PBM. Optimalisasi dapat menggunakan media pembelajaran (Bahtiar, Nunaki, \& Iwan, 2018). Kedepannya, optimalisasi PBM dapat ditambahkan penggunaan media pemnelajan, sehingga hasil belajar yang diperoleh akan optimal.

\section{Simpulan}

Berdasarkan hasil penelitian yang didapatkan bahwa hasil belajar siswa kontrol (konvensional) dan eksperimen (PBM) tidak menunjukkan perbedaan signifikan. Diperlukan beberapa inovasi untuk mengoptimalkan penerapan PBM dalam pembelajaran biologi, khususnya materi invertebrate.

\section{Referensi}

Ayyildiz, Y., \& Tarhan, L. (2018). Problem-based learning in teaching chemistry: enthalpy changes in systems. Research in Science \& Technological Education, 36(1), 35-54. https://doi.org/10.1080/02635143.2017.1366898

Bahtiar, W. A., Nunaki, J. H., \& Iwan, I. I. (2018). Development of Biology Interactive Learning Multimedia on Animal Tissue Topic in The Class XI IPA in SMA Yapis Manokwari. Inornatus: Biology Education Journal, 1(1), 42-58. https://doi.org/10.30862/inornatus.v1i1.26

Baran, M., \& Sozbilir, M. (2018). An Application of Context- and Problem-Based Learning (C-PBL) into Teaching Thermodynamics. Research in Science Education, 48(4), 663689. https://doi.org/10.1007/s11165-016-9583-1

Damopolii, I., Nunaki, J. H., \& Supriyadi, G. (2018). Effect of problem solving learning model on students achievement. Journal of Education Research and Evaluation, 2(1), 1-9. https://doi.org/10.23887/jere.v2i1.12558

Damopolii, I., Yohanita, A. M., Malatta, F. H., \& Yusuf, F. M. (2018). Pengaruh Model Pembelajaran Berbasis Masalah terhadap Hasil Belajar Kognitif Siswa Kelas VII SMP. Edubiotik: Jurnal Pendidikan, Biologi Dan Terapan, 3(01), 43-52. https://doi.org/10.33503/ebio.v3i01.78

Damopolii, I., Yohanita, A. M., Nurhidaya, N., \& Murtijani, M. (2018). Meningkatkan keterampilan proses sains dan hasil belajar siswa melalui pembelajaran berbasis $\begin{array}{llll}\text { inkuiri. JURNAL } & \text { BIOEDUKATIKA, }\end{array}$ https://doi.org/10.26555/bioedukatika.v6i1.8029

Fatmasuci, F. W. (2017). Pengembangan perangkat pembelajaran berbasis masalah berorientasi pada kemampuan komunikasi dan prestasi belajar matematika siswa SMP. Jurnal Riset Pendidikan Matematika, 4(1), 32-42. https://doi.org/10.21831/jrpm.v4i1.11325

Frabun, R. F., Iwan, I., \& Wambrauw, H. L. (2018). The effectiveness of laboratory use in supporting biology practicums in high schools throughout Manokwari Regency. Inornatus: Biology Education Journal, 1(1), 1-9. https://doi.org/10.30862/inornatus.v1i1.109

Hapsari, P. A. (2016). Validitas kartu permainan domino invertebrata untuk 
meningkatkan hasil belajar untuk siswa kelas X SMA. BioEdu, 5(3), 151-159.

Khairi, M., Widyanto, A., \& Agustina, E. (2015). Penggunaan media alami dan media visual dalam meningkatkan hasil belajar siswa pada sub materi invertebrata di mas babun najah banda Aceh. Prosiding Seminar Nasional Biotik, 455-458.

Khoiriyah, A. J., \& Husamah, H. (2018). Problem-based learning: Creative thinking skills, problem-solving skills, and learning outcome of seventh grade students. Jurnal Pendidikan Biologi Indonesia, 4(2), 151-160. https://doi.org/10.22219/jpbi.v4i2.5804

Lawshe, C. H. (1975). A quantitative approach to content validity. Personnel Psychology, $28(4), 563-575$.

Misnasanti, Utami, R. W., \& Suwanto, F. R. (2017). Problem based learning to improve proportional reasoning of students in mathematics learning. AIP Conference Proceedings, 1868, 050002. https://doi.org/10.1063/1.4995129

Mulyanto, H., Gunarhadi, G., \& Indriayu, M. (2018). The Effect of Problem Based Learning Model on Student Mathematics Learning Outcomes Viewed from Critical Thinking Skills. International Journal of Educational Research Review, 3(2), 37-45. https://doi.org/10.24331/ijere.408454

Nargundkar, S., Samandar, S., \& Mukhopadhyay, S. (2014). A Guided Problem-Based Learning (PBL) Approach : Impact on Critical Thinking. Decision Sciences Journal of Innovative Education, 12(2), 91-108. https://doi.org/10.1111/dsji.12030

Pardamean, B. (2012). Measuring change in critical thinking skills of dental students educated in a PBL curriculum. Journal of Dental Education, 76(4), 443-453. https://doi.org/10.1002/j.0022-0337.2012.76.4.tb05276.x

Posangi, N. W., Hasan, A. M., \& Dama, L. (2018). Standardization of science process skills (SPS) assessment instruments in microbiology labs. Inornatus: Biology Education Journal, 1(1), 59-68. https://doi.org/10.30862/inornatus.v1i1.32

Saleh, M. (2013). Strategi pembelajaran fiqh dengan problem-based learning. Jurnal Ilmiah Didaktika, 14(1), 190-220. https://doi.org/10.22373/jid.v14i1.497

Sari, A. I., \& Faizah, U. (2018). Pengembangan lkpd berbantu website pada materi invertebrata untuk melatihkan keterampilan proses sains peserta didik kelas $\mathrm{X}$ SMA. BioEdu, 7(2), 89-99. Retrieved from https://ejournal.unesa.ac.id/index.php/bioedu/article/view/28751

Ulger, K. (2018). The Effect of Problem-Based Learning on the Creative Thinking and Critical Thinking Disposition of Students in Visual Arts Education The Interdisciplinary Journal of Problem-based Learning Article The Effect of ProblemBased Learning on the Creative Think. The Interdisciplinary Journal of ProblemBased Learning, 12(1), 3-6. https://doi.org/10.7771/1541-5015.1649

Watem, M., Nunaki, J. H., \& Wambrauw, H. L. (2018). Profile of Infrastructure and Pedagogic Competencies of Teachers in SMP and SMA/SMK in Waisai District, Raja Ampat Regency, West Papua Province. Inornatus: Biology Education Journal, 1(1), 10-29. https://doi.org/10.30862/inornatus.v1i1.16

Yuliati, Y. (2016). Peningkatan keterampilan proses sains siswa sekolah dasar melalui model pembelajaran berbasis masalah. Jurnal Cakrawala Pendas, 2(2), 71-83. https://doi.org/10.31949/jcp.v2i2.335

Yusuf, I., \& Widyaningsih, S. W. (2018). Pembelajaran PBL berbantuan Lab-Vir melalui Lesson Study dalam meningkatkan kualitas pembelajaran fisika umum di Universitas Papua. Jurnal Pendidikan Fisika (JPF) UM Metro, 6(2), 117-127. https://doi.org/10.24127/jpf.v6i2.1194 